\title{
Sources and emission of greenhouse gases in Danube Delta lakes
}

\author{
Alina Pavel • Edith Durisch-Kaiser • Sorin Balan • \\ Silviu Radan • Sebastian Sobek • Bernhard Wehrli
}

Received: 28 April 2009/Accepted: 12 May 2009/Published online: 9 June 2009

(C) Springer-Verlag 2009

\begin{abstract}
Production of methane and carbon dioxide as well as methane concentrations in surface waters and emissions to the atmosphere were investigated in two flowthrough lake complexes (Uzlina-Isac and Puiu-RosuRosulet) in the Danube Delta during post-flood conditions in May and low water level in September 2006. Retained nutrients fuelled primary production and remineralisation of bioavailable organic matter. This led to an observable net release of methane, particularly in the lakes Uzlina, Puiu and Rosu in May. Input from the Danube River, from redbuds and benthic release contributed to $\mathrm{CH}_{4}$ concentrations in surface waters. In addition to significant river input of $\mathrm{CO}_{2}$, this trace gas was released via aerobic remineralisation within the water column and in top sediments. Emission patterns of $\mathrm{CO}_{2}$ widely overlapped with those of $\mathrm{CH}_{4}$. Generally, greenhouse gas emissions peaked in the lake complex adjacent to the Danube River in May due to strong
\end{abstract}

Responsible editor: Walter Giger

A. Pavel $\cdot$ S. Balan $\cdot$ S. Radan

GeoEcoMar, National Institute for Marine

Geology and Geoecology,

024053 Bucharest, Romania

E. Durisch-Kaiser $\cdot$ S. Sobek $\cdot$ B. Wehrli

ETH, Swiss Federal Institute of Technology,

Institute of Biogeochemistry and Pollutant Dynamics,

8092 Zurich, Switzerland

E. Durisch-Kaiser $\cdot$ S. Sobek $\cdot$ B. Wehrli $(\bowtie)$

Eawag, Swiss Federal Institute of Aquatic

Science and Technology,

6047 Kastanienbaum, Switzerland

e-mail: wehrli@eawag.ch winds and decreased with increasing hydrological distance from the Danube River. Intense remineralisation of organic matter in the Danube Delta lakes results in a net source of atmospheric greenhouse gases.

Keywords Carbon dioxide emissions · Danube delta · Greenhouse gases · Methane emissions · Wetland lakes

\section{Background, aim and scope}

The Danube Delta is the second largest river delta in Europe $\left(5,800 \mathrm{~km}^{2}\right)$ after the Volga Delta. It forms a highly productive transition zone between the Danube river system and the Black Sea. The fluvial delta (49\%) is strongly influenced by river water from the southern Danube branch, Sfântu Gheorghe. The fluvio-marine delta (51\%) is characterised by through-flow and saltwater intrusion from the Black Sea. However, the hydraulic gradient widely prevents saltwater intrusion into the lakes (Panin 1996).

The Delta itself is the vastest compact zone of reed beds in the world (Oosterberg and Bogdan 2000) and effectively filters nutrients and contaminants from the through-flowing water (Friedrich et al. 2003). Compared to other deltas in the world, the Danube Delta is 'relatively' unaffected by anthropogenic input (Oosterberg and Bogdan 2000). Nevertheless, in the last century, several channels were dredged and meanders removed with the purpose of improving navigation and letting water rich in oxygen and nutrient to penetrate deeper into the delta to increase fish production. Other changes include the reclamation of about $20 \%$ of the delta area as agricultural polders or fishponds, which increased eutrophication.

Transition towards hypertrophy has affected biodiversity and productivity of most aquatic and wetland systems in the 
Danube Delta. Compared to the early 1960s, the loads of inorganic $\mathrm{N}$ and $\mathrm{P}$ of the River Danube increased five and threefold, respectively. Eutrophication became a serious problem not only in the delta lakes but also in the coastal Black Sea (Friedrich et al. 2003) and was recognised to cause changes in food web structures (Cociasu et al. 1996) and also to increase the potential for greenhouse gas production and export of carbon dioxide and methane to the Black Sea shelf and the atmosphere (Amouroux et al. 2002).

All Danube Delta lakes (DDL) sampled in this study (Fig. 1) are eutrophic in respect to $\mathrm{N}$ and $\mathrm{P}$ concentrations (Oosterberg and Bogdan 2000). Retention of nutrients, their transformation into phytoplankton and plant biomass and subsequent decomposition in sediments may lead to the release of greenhouse gases from DDL. Next to carbon dioxide $\left(\mathrm{CO}_{2}\right)$, methane $\left(\mathrm{CH}_{4}\right)$ represents a potent greenhouse gas in global climate, contributing about $15 \%$ of the anthropogenic greenhouse effect (Cicerone and Oremland 1988). Most natural $\mathrm{CH}_{4}$ emissions are linked to wetlands ( $83 \%$, IPCC 2007). Emission rates are highly variable over space and time, e.g. local emissions from most types of natural wetlands can vary by a few orders of magnitude over a few metres (IPCC 2001; Pavel 2009). Although wetlands act as a source of $\mathrm{CH}_{4}$, most may also act as a $\mathrm{CO}_{2}$ sink due to photosynthesis and sequestration of organic matter in wetland soils or sediments (Brix et al.
2001). In this study, benthic releases of methane were measured to follow up on the remineralisation of organic biomass in lake sediments. Determining the flux of $\mathrm{CO}_{2}$ and $\mathrm{CH}_{4}$ to the atmosphere finally allowed linking nutrient dynamics and greenhouse gas emissions from large wetland lakes. An earlier, more detailed publication included measurements of nutrient retention and total nitrogen and phosphorous export (Durisch-Kaiser et al. 2008). In this short paper, we overview the investigations on the greenhouse gases $\mathrm{CO}_{2}$ and $\mathrm{CH}_{4}$.

\section{Materials and methods}

\subsection{Study sites}

Water samples were taken from five through-flow lakes (Table 1) located in the Romanian part of the Danube Delta (see Fig. 1). The Lakes Uzlina and Isac (lake complex I) belong to the fluvial delta formed by the Gorgova-Uzlina lake complex (Oosterberg and Bogdan 2000) and are strongly influenced by Danube river water. The other three, Ls. Puiu, Rosu and Rosulet (lake complex II), are situated further distant from the Danube branches and belong to the fluvio-marine delta. Lakes Uzlina, Rosu and Rosulet qualify as turbid systems, whereas Lake Isac behaves as

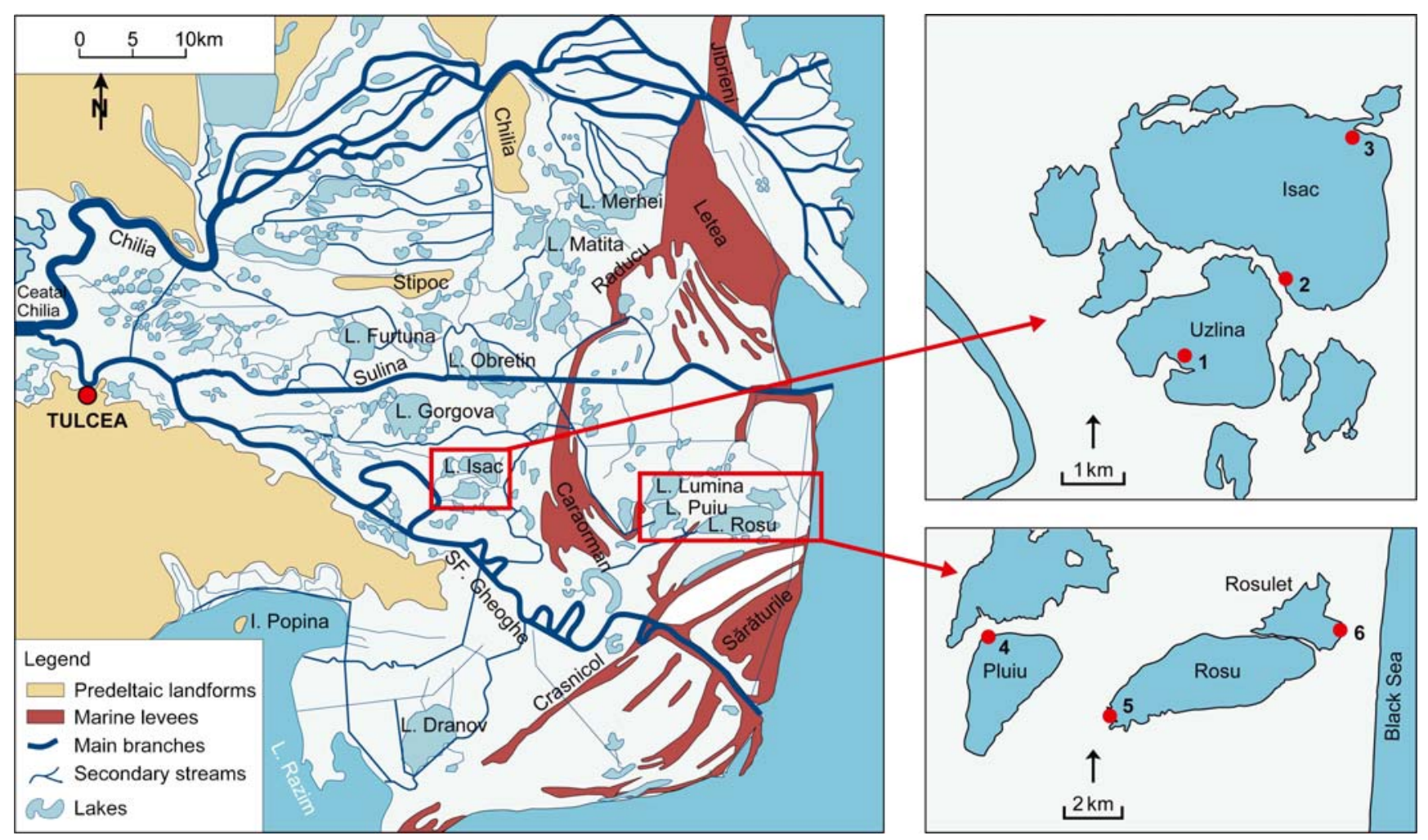

Fig. 1 Geographic map of the studied Danube Delta lakes with the sampling stations: 1 Uzlina-in, 2 Uzlina-out, 3 Isac-out, 4 Puiu-in, 5 Rosu-in and 6 Rosulet-out. Sulina and Sfantu Gheorghe represent the main branches of the River Danube in the delta influencing the investigated lakes 
Table 1 Benthic fluxes of methane and sulphate calculated from the sediment-water interface in the different lakes in May and September 2006

\begin{tabular}{|c|c|c|c|c|}
\hline \multirow[b]{3}{*}{ Sampling time } & \multicolumn{2}{|l|}{$\mathrm{CH}_{4}$} & \multicolumn{2}{|c|}{$\mathrm{SO}_{4}^{2-}$} \\
\hline & \multicolumn{4}{|c|}{$\left(\mu \mathrm{mol} \mathrm{m}{ }^{-2} \mathrm{~h}^{-1}\right)$} \\
\hline & May & September & May & September \\
\hline Uzlina-in & 299 & 86 & -324 & -19 \\
\hline Uzlina-out & 67 & n. $d$. & -90 & n. d. \\
\hline Isac-out & 152 & 138 & -88 & -15 \\
\hline Puiu-in & 377 & 99 & -188 & -80 \\
\hline Rosu-in & 291 & 203 & -267 & -5 \\
\hline Rosulet-out & 78 & 116 & -248 & -113 \\
\hline
\end{tabular}

For experimental details, see Durisch-Kaiser et al. (2008)

n. $d$. not determined

an intermediate, between clear and turbid and lacks floating vegetation and large loads of suspended solids (Coops et al. 1999). Lake Rosu is separated only by partially submerged sand bars, reed and floating reed islands (Phragmites sp. plaurs) from the outflow of Lake Rosulet and represents the largest lake within the Danube Delta. The water level of the River Danube and the associated delta rises to highest levels between April and June and then decreases to lowest levels in September and October (Panin 1996). The hydraulic residence times during the sampling campaigns varied between 10 and 29 days. In May 2006, we encountered post-flooding conditions with extremely high water flow compared to September.

\subsection{Sampling and analyses}

For methane analysis, water column and sediment pore water samples were collected in May and September 2006 at the stations outlined in Fig. 1. Water samples were retrieved using a Niskin bottle from three depths $(\sim 0.5-\mathrm{m}$ depth, $\sim 1.5-$ to $3-\mathrm{m}$ depth and $\sim 0.5 \mathrm{~m}$ above sediment). Pore water samples were collected at $1-\mathrm{cm}$ intervals from the top sediment to $\sim 0.5-\mathrm{m}$ depth using dialysis pore water samplers or 'peepers' (Hesslein 1976; Urban et al. 1997). Samples were transferred bubble-free into $25-\mathrm{mL}$ crimpseal bottles, poisoned with a saturated solution of $\mathrm{CuCl}$, sealed gastight and stored upside down for further analyses at Eawag (Switzerland). Quantification of methane was accomplished using gas chromatography (JAS-UNIS; Durisch-Kaiser et al. 2008). For a calibration curve, standards of 100 and $1,000 \mathrm{ppm}$ were used (Scotty Speciality Gases, USA).

Concentrations of $\mathrm{CO}_{2}$ and $\mathrm{CH}_{4}$ in lake surface water were determined using a continuous-flow high-resolution technique. Water was continuously collected in situ from a depth of $1 \mathrm{~m}$ and pumped $\left(150 \mathrm{~L} \mathrm{~h}^{-1}\right)$ through a system of three consecutively aligned polypropylene fibre filters $(<2-\mathrm{mm}$ pore size) to separate large particles from the samples prior to equilibration between water. Simultaneous recording of GPS coordinates allowed for concentration measurements at high spatial resolution.

Gas measurements were performed using an INNOVA Bruel and Kjaer 1312 multi-gas monitor based on photoacoustic infrared detection. The gas samples were pumped from the equilibrator headspace into the detection cell. The infrared light was emitted by a pulsating source, passed a narrow-band optical filter and was selectively absorbed by the gas trapped. The gas temperature increased and decreased in response to the pulsating light transmitter. This caused a variation of the gas pressure in the closed cell. Two ultrasensitive microphones located in the cell walls measure the pressure wave, which was directly proportional to the gas concentration. Carbon dioxide and methane concentrations were measured in parallel using different optical filters. The detection limits were 3 ppmv for $\mathrm{CO}_{2}$ and $0.1 \mathrm{ppmv}$ for $\mathrm{CH}_{4}$. Data were provided in 2-min intervals. Parameters that governed gas exchange across the water-air interface, i.e. wind speed, water and air temperature, were also measured aboard ship. Wind speed was measured at about 12-m height (Pavel, submitted).

\subsection{Flux calculations}

The gas fluxes across the water-air interface were calculated from the transfer velocity using the relations of Crusius and Wanninkhof (2003) and the Schmidt numbers of the gases

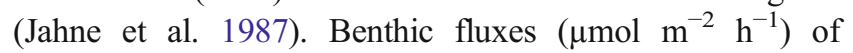
methane across the water-sediment interface were calculated along linear concentration gradients at the sediment-water interface using Fick's first law of diffusion. A molecular diffusion coefficient of $1.57 \times 10^{-9} \mathrm{~m}^{2} \mathrm{~s}^{-1}$ was used for methane.

\section{Results and discussion}

\subsection{Diffusive release of greenhouse gases from sediments}

Benthic remineralisation of deposited organic biomass contributed to a net greenhouse gas release from both lake complexes (see Fig.1 and Table 1). Methane release from shallow sediments was high at station Uzlina-in, in comparison to the other lakes in complex I in May and September, and compared well to other eutrophic and hypertrophic lakes (Matthews et al. 2005; Huttunen et al. 2006). The fast diffusion rates were correlated with high input of internally produced biomass. Such a particularly 
Fig. $2 \mathrm{CO}_{2}$ flux distribution map for Lake Uzlina in May 2006. Emissions are expressed in millimoles per square metre per hour (red, high emission; blue, low emission)

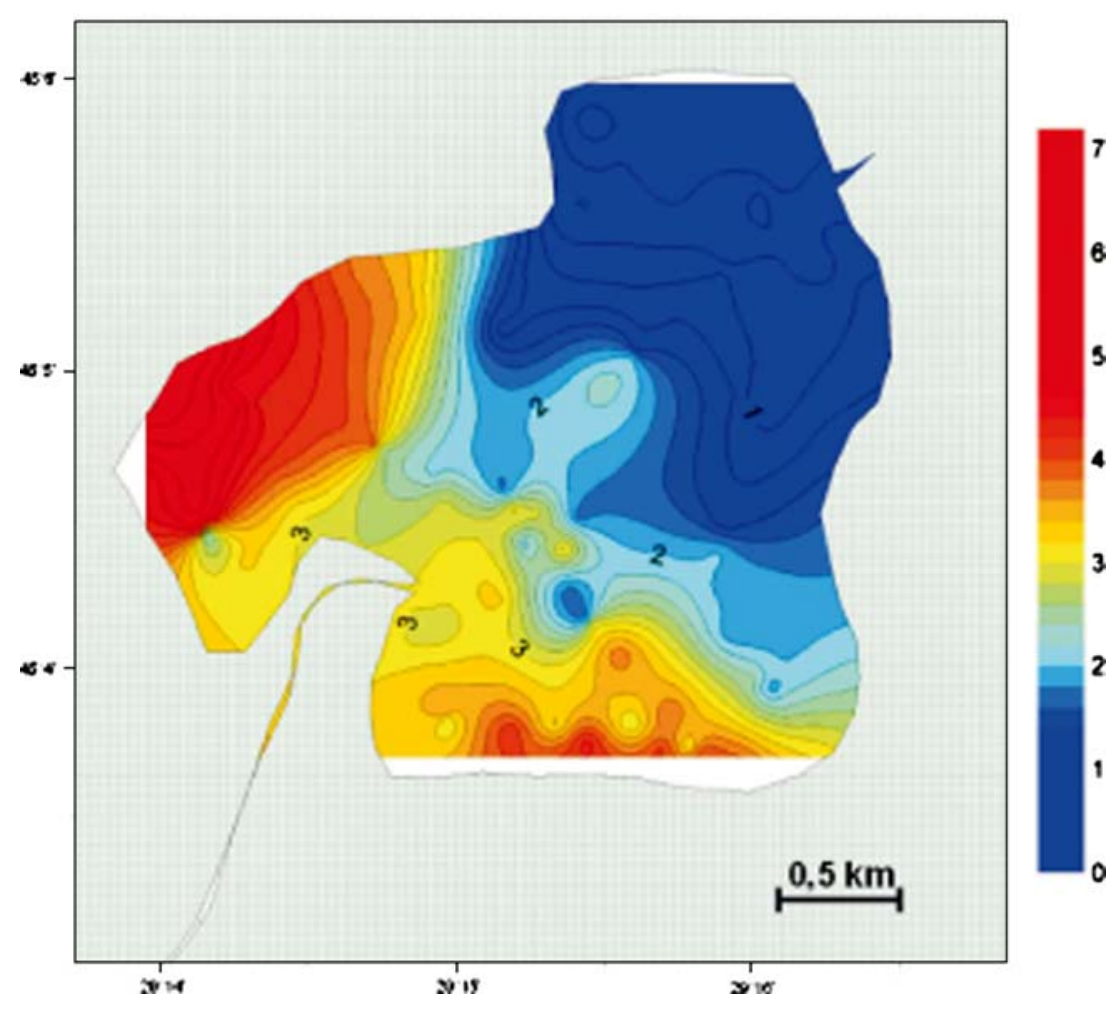

intense algal bloom was observed in Lake Uzlina in September. In addition, deposition of riverine organic particles added to the sediment organic matter load in this lake, which is located closest to one Danube branch.

Benthic release of methane decreased along throughflow in lake complex I (see Table 1), as expected for less intense organic matter deposition at the outlet of lakes Uzlina and Isac compared to the inlet. Sulphate reduction and methanogenesis showed a similar sedimentary turnover in May. In September, methanogenesis clearly dominated anaerobic decomposition in sediments.

Leaving Lake Isac, water was diverted through a series of channels and reed beds before it entered lake complex II at station Puiu-in. There, benthic release of methane was highest among all lakes in May (see Table 1), indicating that additional inflow from canals leads to substantial organic matter deposition at the inlet to Lake Puiu. Benthic release of methane decreased along the flow path in the Puiu-Rosu

Table 2 Surface water concentrations (mean $\pm \mathrm{SD}$ ) and fluxes across the air-water interface (mean $\pm \mathrm{SD}$ ) of $\mathrm{CO}_{2}$ and $\mathrm{CH}_{4}$ from the Danube Delta lake complexes I and II

\begin{tabular}{|c|c|c|c|c|c|c|c|c|c|c|}
\hline \multirow[b]{2}{*}{$\begin{array}{l}\text { Sampling date in } \\
2006 \text { (month) }\end{array}$} & \multicolumn{5}{|c|}{ Lake complex I } & \multicolumn{5}{|c|}{ Lake complex II } \\
\hline & $\begin{array}{l}\text { Uzlina } \\
\text { May }\end{array}$ & Isac & Puiu & Rosu & Rosulet & $\begin{array}{l}\text { Uzlina } \\
\text { September }\end{array}$ & Isac & Puiu & Rosu & Rosulet \\
\hline $\begin{array}{l}\mathrm{CO}_{2} \text { concentration } \\
(\mu \mathrm{M})\end{array}$ & $103 \pm 49$ & $49 \pm 35$ & $142 \pm 77$ & $110 \pm 70$ & $63 \pm 69$ & $18 \pm 10$ & $27 \pm 17$ & n.d. & $26 \pm 27$ & n.d. \\
\hline $\begin{array}{l}\mathrm{CH}_{4} \text { concentration } \\
(\mathrm{nM})\end{array}$ & $714 \pm 257$ & $569 \pm 370$ & $891 \pm 424$ & $534 \pm 113$ & $738 \pm 575$ & $644 \pm 224$ & $613 \pm 161$ & n.d. & $538 \pm 119$ & n.d. \\
\hline $\begin{array}{l}\mathrm{CO}_{2} \text { air-water flux } \\
\left(\mathrm{mmol} \mathrm{m}^{-2} \mathrm{~h}^{-1}\right)\end{array}$ & $2.3 \pm 1.3$ & $4.9 \pm 4.5$ & $3.4 \pm 2.0$ & $2.4 \pm 1.8$ & $0.7 \pm 1.0$ & $0.2 \pm 0.4$ & $1.2 \pm 1.7$ & n.d. & $0.1 \pm 0.4$ & n.d. \\
\hline $\begin{array}{c}\mathrm{CH}_{4} \text { air-water flux } \\
\left(\mu \mathrm{mol} \mathrm{m} \mathrm{m}^{-2} \mathrm{~h}^{-1}\right)\end{array}$ & $18 \pm 7$ & $80 \pm 51$ & $23 \pm 11$ & $13 \pm 3$ & $11 \pm 9$ & $26 \pm 9$ & $62 \pm 17$ & n.d. & $7 \pm 2$ & n.d. \\
\hline
\end{tabular}

Positive air-water fluxes indicate emissions to the atmosphere

n.d. not determined 
system in May. The observation could be tentatively linked to diminishing nutrient levels and primary productivity along the lake system. After the intense production period in summer, the benthic releases of $\mathrm{CH}_{4}$ were highest in Lake Rosu in September, which could indicate that this terminal system collected significant organic carbon fluxes during summer.

\subsection{Greenhouse gas emissions from Danube Delta lakes}

Seasonal monitoring of greenhouse gas fluxes from surface waters of selected lakes showed that $\mathrm{CO}_{2}$ and $\mathrm{CH}_{4}$ emissions peaked in lake complex I, particularly in Lake Isac in May, due to strong winds (Table 2). Spatial patterns in gas release only partially correlated with water column concentrations and benthic effluxes of methane (see Table 1 and Fig. 2), suggesting that several factors like lake depths, hydrology, locally different wind-driven mixing, water column temperature and methanotrophic activity might govern diffusive water-air fluxes (Pavel 2009). Water column concentrations and measured emission rates compare well with published values for eutropic and hypertrophic lakes (e.g. Cole and Caraco 2001; Casper et al. 2000). The high standard deviations reflect the high spatial variability of fluxes to the atmosphere (see Table 2).

In lake complex I in May, concentrations of $\mathrm{CO}_{2}$ were highest in Lake Uzlina due to massive inflow of $\mathrm{CO}_{2}$-rich water from the Danube River and surrounding reed beds and due to remineralisation of organic matter within the lake. River water is known to be generally supersaturated with $\mathrm{CO}_{2}$ (Cole and Caraco 2001; Richey et al. 2002). Danube water contained approximately $37 \mu \mathrm{M} \mathrm{CO}_{2}$ before entering lake complex I (unpublished data). This value was lower than the average concentration of $103 \mu \mathrm{M}$ found in Lake Uzlina in spring, implying that remineralisation of organic matter in reed beds and lake sediments liberated significant amounts of $\mathrm{CO}_{2}$, leading to a diffusive emission from surface water to the atmosphere on the order of $2.3 \mathrm{mmol} \mathrm{m}^{-2} \mathrm{~h}^{-1}$ in May. About twice as much $\mathrm{CO}_{2}$ was released from Lake Isac $\left(4.9 \mathrm{mmol} \mathrm{m}^{-2} \mathrm{~h}^{-1}\right)$ due to strong winds. Note that $\mathrm{CH}_{4}$ concentrations in general were more homogeneously distributed than $\mathrm{CO}_{2}$.

In Lake Puiu (lake complex II), water column concentrations of $\mathrm{CO}_{2}$ and $\mathrm{CH}_{4}$ were strongly impacted by input of water from the Crisan channel in the western part and highest among all lakes investigated in May (see Table 2). Furthermore, emission of $\mathrm{CH}_{4}$ could be related to high benthic $\mathrm{CH}_{4}$ release in May (see Table 2). With further longitudinal transport of water masses to Lake Rosu, surface water concentrations of $\mathrm{CO}_{2}$ decreased, whereas $\mathrm{CH}_{4}$ stayed fairly constant (see Table 2). In comparison, surface emissions of $\mathrm{CO}_{2}$ and $\mathrm{CH}_{4}$ decreased along longitudinal transport to minimum values in Lake Rosulet, a lake in which discharge is most stagnant (see Table 1).

\section{Conclusions}

This short account shows that water column $\mathrm{CO}_{2}$ and $\mathrm{CH}_{4}$ in the Danube Delta lakes derived not only from benthic remineralisation but also from input of river or canal water which, for example, can be clearly observed at Uzlina-in and Puiu-in. Emissions of $\mathrm{CO}_{2}$ and $\mathrm{CH}_{4}$ to the atmosphere were only partially coupled to surface water $\mathrm{CO}_{2}$ and $\mathrm{CH}_{4}$ concentrations and benthic diffusion rates of methane, which implied that other factors such as water depths, seasonally different wind strengths and methanotropic activity played an important role. We observed high $\mathrm{CO}_{2}$ and $\mathrm{CH}_{4}$ emissions in spring when strong winds prevailed and reduced outgassing in the fall due to stagnant conditions, lower temperature and calm wind conditions.

In summary, in this vast wetland, greenhouse gas production and emission can be positively correlated to patterns of inorganic nutrient and organic matter input, and the Danube Delta lakes are net sources of $\mathrm{CO}_{2}$ and $\mathrm{CH}_{4}$ to the atmosphere. This study also shows that improving the spatiotemporal resolution of greenhouse gas analyses in such complex wetland-lake environment holds great promise in linking hotspots of emissions with the governing biogeochemical and physical processes.

Acknowledgements This work was financed by the Swiss National Science Foundation, the Swiss Agency for Development and Cooperation and the Romanian Ministry for Education and Research within the framework of the Swiss-Romanian cooperation programme on 'Environmental Science and Technology in Romania-ESTROM'. The reported study was performed in the project WASEDY focusing on water and sediment dynamics affecting nutrient cycles and greenhouse gas emissions in the Danube Delta. The authors are grateful to the staff of the $\mathrm{R} / \mathrm{V}$ Istros for their enormous assistance with water column and sediment sampling, and other field work. We specially thank Christian Dinkel for all his logistical support.

\section{References}

Amouroux D, Roberts G, Rapsomanikis S, Andreae MO (2002) Biogenic gas $\left(\mathrm{CH}_{4}, \mathrm{~N}_{2} \mathrm{O}\right.$, DMS $)$ emission to the atmosphere from near-shore and shelf waters of the north-western Black Sea. Estuar Coast Shelf Sci 54:575-587

Brix H, Sorrell BK, Lorenzen B (2001) Are Phragmites-dominated wetlands a net source or net sink of greenhouse gases? Aquat Bot 69:313-324

Casper P, Maberly SC, Hall GH, Finlay BJ (2000) Fluxes of methane and carbon dioxide from a small productive lake to the atmosphere. Biogeochemistry 49:1-19

Cicerone RJ, Oremland RS (1988) Biogeochemical aspects of atmospheric methane. Glob Biogeochem Cycles 2:299-327

Cociasu A, Dorogan L, Humborg C, Popa L (1996) Long-term ecological changes in Romanian coastal waters of the Black Sea. Mar Pollut Bull 32(1):32-38 
Cole JJ, Caraco NF (2001) Carbon in catchments: connecting terrestrial carbon losses with aquatic metabolism. Mar Freshw Res 52(1):101-110

Coops H, Hanganu J, Tudor M, Oosterberg W (1999) Classification of Danube Delta lakes based on aquatic vegetation and turbidity. Hydrobiologia 415:187-191

Crusius J, Wanninkhof R (2003) Gas transfer velocities measured at low wind speed over a lake. Limnol Oceanogr 4:1010-1017

Durisch-Kaiser E, Pavel A, Doberer A, Reutimann J, Balan S, Sobek S, Radan S, Wehrli B (2008) Nutrient retention, total N and P export, and greenhouse gas emission from the Danube Delta lakes. Geo-Eco-Marina 14:81-90

Friedrich J, Dinkel C, Grieder E, Radan S, Secrieru D, Steingruber S, Wehrli B (2003) Nutrient uptake and benthic regeneration in Danube Delta lakes. Biogeochemistry 64:373-398

Hesslein RH (1976) An in-situ sampler for close interval pore water studies. Limnol Oceanogr 21:912-914

Huttunen JT, Vaisanen TS, Hellsten SK, Martikainen PJ (2006) Methane fluxes at the sediment-water interface in some boreal lakes and reservoirs. Boreal Environ Res 11(1):27-34

IPCC (2001) Climate change 2001: 3rd assessment report. Intergovernmental Panel on Climate Change. Cambridge University Press, Cambridge
IPCC (2007) Climate Change 2007: 4th assessment report. Intergovernmental Panel on Climate Change. Cambridge University Press, Cambridge

Jahne B, Munnich KO, Bosinger R, Dutzi A, Huber W, Libner P (1987) On the parameters influencing air-water gas-exchange. J Geophys Res Oceans 92:1937-1949

Matthews DA, Effler SW, Matthews CM (2005) Long-term trends in methane flux from the sediments of Onondaga Lake, NY: sediment diagenesis and impacts on dissolved oxygen resources. Arch Hydrobiol 163:435-462

Oosterberg W, Bogdan L (2000) Ecological gradients in the Danube Delta lakes-water quality. RIZA rapport 2000.015, pp 51-70

Panin N (1996) Danube Delta - genesis, evolution and sedimentology. Geo-Eco-Marina 1:11-34

Pavel A (2009) Dynamics of greenhouse gas production, consumption and emission from Danube Delta lakes. PhD thesis, University of Bucharest

Richey JE, Melack JM, Aufdenkampe AK, Ballester V, Hess LL (2002) Outgassing from Amazonian rivers and wetlands as a large tropical source of atmospheric $\mathrm{CO}_{2}$. Nature 416:617-620

Urban NR, Dinkel C, Wehrli B (1997) Solute transfer across the sediment surface of a eutrophic lake: porewater profiles from dialysis samplers. Aquat Sci 59:1015-1621 